\title{
Undetectable pre-ablation thyroglobulin levels in patients with differentiated thyroid cancer: it is not always what it seems
}

\author{
Níveis indetectáveis de tireoglobulina pré-ablação em pacientes \\ com câncer de tireoide: nem sempre é o que parece
}

Fabián Pitoia', Maria F. Bueno', Erika Abelleira', Maria E. Salvai', Liliana Bergoglio ${ }^{2}$, Markus Luster ${ }^{3}$, Hugo Niepomniszcze ${ }^{1 \dagger}$

' Division of Endocrinology, Hospital de Clinicas, University of Buenos Aires, Buenos Aires, Argentina ${ }^{2}$ Endocrine Laboratory, Hospital de Clinicas, Córdoba, Argentina ${ }^{3}$ Department of Nuclear Medicine, University of Marburg, Germany + In memoriam
Correspondence to: Fabián Pitoia

Division of Endocrinology Hospital de Clinicas, University of Buenos Aires Av. Córdoba, 2351, $5^{\circ}$ piso, 1120 - Buenos Aires, Argentina fpitoia@intramed.net

Received on Sept/30/2012 Accepted on Nov/12/2012

\section{ABSTRACT}

Objective: To establish the frequency of UTg (undetectable pre-ablation thyroglobulin) inTgAbnegative patients and to evaluate the outcome in the follow-up. Subjects and methods: We retrospectively reviewed 335 patients' records. Twenty eight patients (9\%) had UTg. Mean follow-up was $42 \pm 38$ months. All subjects had undergone total thyroidectomy, and lymph nodes were positive in $13(46 \%)$ patients. $\mathrm{Tg}$ and $\mathrm{TgAb}$ levels were measured 4 weeks after surgery by IMA technology in hypothyroid state. No evidence of disease (NED) status was defined as undetectable $(<1 \mathrm{ng} / \mathrm{mL}$ ) stimulatedTg and negative Tg-Ab and/or negative WBS, together with normal imaging studies. Results: Seventeen patients $(61 \%)$ were considered with NED. Four patients (14\%) had persistent disease (mediastinum, $n=1$, lung $n=2$, unknown $n=1)$, and $7(25 \%)$ had detectableTgAb by other method during their follow-up. Conclusions: UTg levels usually is associated to a complete surgery. However, in a low percentage of patients, this may be related to false negative Tg orTgAb measurement. Arq Bras Endocrinol Metab. 2013;57(4):300-6

\section{Keywords}

Undetectable thyroglobulin levels; thyroglobulin; ablation; thyroid; cancer

\section{RESUMO}

Objetivo: Estabelecer a frequência de U Tg (tireoglobulina indetectável pré-ablação) em pacientes com TgAb negativo e avaliar o prognóstico no seguimento. Sujeitos e métodos: Foram analisados retrospectivamente 335 registros de pacientes. Vinte e oito pacientes (9\%) tiveram UTg. 0 acompanhamento médio foi de $42 \pm 38$ meses. Todos os participantes receberam uma tireoidectomia total, e os linfonodos foram positivos em $13(46 \%)$ pacientes. Tg e TgAb foram medidos quatro semanas após a cirurgia pelo método IMA em estado de hipotireoidismo. $A$ não evidência de doença (NED) foi definida como níveis indetectáveis $(<1 \mathrm{ng} / \mathrm{mL}$ ) deTg estimulada com anticorpos anti-Tg negativos e/ou PCl negativo, com estudos de imagem normais. Resultados: Dezessete pacientes (61\%) foram considerados com NED. Quatro pacientes (14\%) tiveram doença persistente (mediastino, $n=1$, pulmão $n=2, n=$ desconhecido 1), e 7 (25\%) apresentavam anticorpos anti-Tg detectáveis por outro método durante acompanhamento. Conclusões: UTg geralmente indica uma cirurgia completa. No entanto, em uma pequena porcentagem de pacientes, pode estar relacionada com uma medida de Tg ou de anticorpos anti-Tg falsamente negativos. Arq Bras Endocrinol Metab. 2013;57(4):300-6

\section{Descritores}

Níveis de tiroglobulina indetectáveis; tireoglobulina; câncer; tiroide 


\section{INTRODUCTION}

S erum thyroglobulin $(\mathrm{Tg})$ is usually used as a post$\bigcirc$-surgical marker to define disease status in patients with differentiated thyroid cancer $(1,2)$. Up to $20 \%$ of patients may present Tg-Antibodies ( $\mathrm{TgAb}$ ), which might obscure the evidence of detectable $\operatorname{Tg}(3,4)$. TgAb are also considered as surrogate markers for the persistence of disease $(1,2,6-8)$.

Variability in the detection of $\mathrm{TgAb}$ according to the methodology employed (immunometric, IMA $v s$. radioimmunometric, RIA) is a well-known situation with many specimens with interfering $\mathrm{TgAb}$ being misclassified as TgAb-negative when manufacturer-recommended cutoff values are considered (9). This situation is even more complex when patients are followed up with measurements by different methods, as it is common practice in Argentina, mainly when patients are evaluated in private practices.

On the other hand, undetectable pre-ablation stimulated $\mathrm{Tg}(\mathrm{U} \mathrm{Tg})$ is a condition that might indicate complete previous surgery, secretion of non-immunoreactive $\mathrm{Tg}$, or the presence of non-measurable serum $\operatorname{TgAb}(9-12)$.

The objective of this study was to establish the frequency of $U \mathrm{Tg}$ in patients with negative $\mathrm{TgAb}$ measured by IMA technology (considering the analytical sensitivity for each methodology), and to evaluate the outcome of these patients in the follow-up.

\section{SUBJECTS AND METHODS}

Approval from the review board of our institution was obtained for the study. We retrospectively reviewed the charts of 335 patients with diagnosis of differentiated thyroid carcinoma between January 2000 and May 2010: papillary thyroid cancer, $\mathrm{n}=325(97 \%)$, and follicular thyroid cancer, $\mathrm{n}=10(3 \%)$, who had undergone total thyroidectomy (with or without neck dissection), and were radioiodine-ablated after surgery in hypothyroid state $(\mathrm{TSH}$ levels $>30 \mathrm{mU} / \mathrm{L}$ ). All included subjects had to have pre-ablation U-Tg associated with undetectable $\mathrm{TgAb}$ considering the analytical sensitivity as a cutoff value for each assay (IMA methodology), with no suspicion of metastatic systemic disease at diagnosis. Patients had to be followed up for at least 12 months after ablation.

Twenty eight patients met these criteria, 27 women and 1 man (Table 1). All of them were diagnosed with papillary thyroid cancer. The prevalence of $\mathrm{U} \mathrm{Tg}$ in this series was $9 \%$. Mean age of included patients was $48 \pm$ 14 years, TNM Stages (American Joint Committee of Cancer, $6^{\text {th }}$ Edition) were: Stage I: $\mathrm{n}=17$, Stage II: $\mathrm{n}$ $=2$, Stage III: $\mathrm{n}=5$, Stage IV: $\mathrm{n}=4$. Risk of Recurrence according to the Latin American Thyroid Society (LATS) classification was: very low, $\mathrm{n}=3$; low $\mathrm{n}=12$; high $\mathrm{n}=13$ (2); and according to American Thyroid Association (ATA) was: low, $\mathrm{n}=15$, intermediate, $\mathrm{n}=$ 5 , high, $\mathrm{n}=8$ (1).

Diffuse Hashimoto's thyroiditis was observed in the pathology of $11 / 28(39 \%)$ of the patients. Mean follow-up for the full cohort of patients was $42 \pm 38$ months (range 13-153 months).

\section{Methods}

All included subjects received total thyroidectomy in a specialized center and lymph node dissection was performed in 18/28 (64\%) patients.

Lymph nodes were dissected when intrasurgical anatomopathological analysis proved the presence of metastasis (frozen section). This was true for $8 / 18$ (44\%) patients (central and lateral neck dissection). In the remaining subjects, $10 / 18(66 \%)$, lymph node dissection in the central neck compartment (level VI) was mostly indicated after confirmation of tumor size (T3) and/or when suspicious lymph nodes were noted during the surgical procedure. Five out of these 10 patients finally had metastatic microscopic central lymph nodes. In these series, the prevalence of lymph node metastasis was $46 \%$ ( $13 / 28$ patients), as shown in table 1 .

All patients received radioiodine thyroid remnant ablation. Mean radioiodine ablative activity was $123 \pm$ $40 \mathrm{mCi}$ 131-I. Tg levels were measured 4 weeks after surgery in the hypothyroid state $(\mathrm{TSH}>70 \mathrm{mUI} / \mathrm{L}$ in all cases) and $\mathrm{TgAb}$ levels were assessed by IMA methodology in four different reference laboratories. $\mathrm{Tg}$ was measured by Elecsys $\mathrm{Tg}$ Electrochemiluminescence Immunoassay (Roche Diagnostics $\mathrm{GmbH}$, Mannheim, Germany), which has a limit of detection of $0.5 \mathrm{ng} /$ $\mathrm{mL}$; Immulite 1000 and Immulite $2000 \mathrm{Tg}$ Chemiluminiscence (Siemens Corp., Los Angeles, CA), with an analytical sensitivity (AS) of $0.2 \mathrm{ng} / \mathrm{mL}$. For TgAb: Elecsys Anti-Tg Electrochemiluminescence Immunoassay (RSR Ltd., Pentwyn, Cardiff, U.K.). A value $>20$ $\mathrm{IU} / \mathrm{mL}$ was regarded as positive. Immulite chemiluminescent immunometric assay method was also used (Siemens Corp., Los Angeles, CA). Values > 20 kIU/ liter were considered as positive. 
Table 1. Characteristics of the 28 patients with papillary thyroid cancer with undetectable $\mathrm{Tg}$ levels after total thyroidectomy and radioiodine ablation

\begin{tabular}{|c|c|}
\hline & $\mathrm{n}=\mathbf{2 8}$ patients \\
\hline \multicolumn{2}{|l|}{ Sex } \\
\hline $\mathrm{M} / \mathrm{F}$ & $27(96.5 \%) / 1(3.5 \%)$ \\
\hline Mean age (range) & $48 \pm 14(27-73)$ \\
\hline Papillary thyroid cancer & $28(100 \%)$ \\
\hline \multicolumn{2}{|l|}{ Variant } \\
\hline Classic & $23(82.5 \%)$ \\
\hline Follicular & $1(3.5 \%)$ \\
\hline Oncocytic & $1(3.5 \%)$ \\
\hline Tall Cell & $2(7 \%)$ \\
\hline Diffuse sclerosing & $1(3.5 \%)$ \\
\hline \multicolumn{2}{|l|}{ TNM stage } \\
\hline । & $17(61 \%)$ \\
\hline$\|$ & $2(7 \%)$ \\
\hline III & $5(18 \%)$ \\
\hline IV & $4(14 \%)$ \\
\hline \multicolumn{2}{|l|}{ ATA risk of recurrence } \\
\hline Low & $15(54 \%)$ \\
\hline Intermediate & $5(18 \%)$ \\
\hline High & $8(28 \%)$ \\
\hline Bilateral tumor & $2(7 \%)$ \\
\hline Multifocal tumor & $6(21 \%)$ \\
\hline \multicolumn{2}{|l|}{ LN metastasis } \\
\hline Present & $18(64 \%)$ \\
\hline Central & $10(71 \%)$ \\
\hline Central and lateral & $8(29 \%)$ \\
\hline No neck dissection & $10(36 \%)$ \\
\hline Mean radioiodine dose for $\mathrm{RA}$ (mCi) & $123 \pm 40$ \\
\hline Follow-up in months (range) & $42 \pm 38(13-153)$ \\
\hline
\end{tabular}

Measurement of $\operatorname{Tg}$ and $\mathrm{TgAb}$ in different centers is a common practice in our country, as health care insurance companies reimburse the cost of laboratory tests according to their own agreement with specific institutions.

\section{Follow-up}

After thyroid remnant ablation, all patients were started on thyroid hormone therapy. Thyroid ultrasound scanning (US) was performed in all patients by using an 11 $\mathrm{MHz}$ linear array transducer every 6 months. Twelve to eighteen months after ablation, TSH-stimulated $\mathrm{Tg}$ was measured (in 18 patients after two $0.9 \mathrm{mg}$ rhTSH administration and in 10 after thyroid hormone wi- thdrawal). In $16 / 28$ patients whole body scan (WBS) was also performed, in 6 after administration of $4 \mathrm{mCi}$ of $131-\mathrm{I}$, and in the remaining 10 patients, after a new radioiodine dose (mean activity of $96 \pm 40 \mathrm{mCi} \mathrm{131-}$ I). No new radioiodine doses or diagnostic WBS were performed after 24 months of follow-up at the moment of the analysis.

In patients with measurable $\mathrm{Tg}$ in the follow-up (under L-T4 treatment or thyroid hormone withdrawal), and/or abnormal neck ultrasound, and/or persistence of TgAb after a 24-36 months of follow-up, morphological evaluations, including computed tomography $(\mathrm{n}=5)$, and ${ }^{18}$ fluorodesoxyglucose positron emission tomography $(\mathrm{n}=3)$, were performed.

The no evidence of disease (NED) status was defined after the measurement of undetectable stimulated $\mathrm{Tg}$ in association with negative $\mathrm{TgAb}$ and/or negative diagnostic or post-dose WBS, together with ultrasonography and/or CT/MRI/PET-CT showing no evidence of disease.

\section{Statistical analysis}

Quantitative data were expressed as means and SD, and qualitative data were expressed in percentages.

\section{RESULTS}

The clinical characteristics of the 28 patients with $\mathrm{U} \mathrm{Tg}$ are shown in table 1 , and the outcome of these patients is presented in figure 1 .

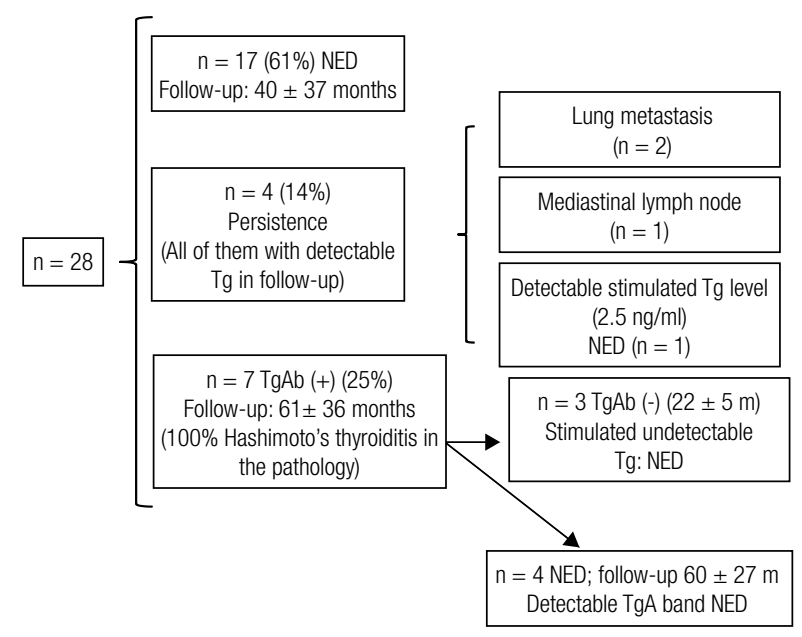

NED: no evidence of clinical disease; Tg: thyroglobulin; TgAb: anti-thyroglobulin antibodies; (+): positive; (-): negative

Figure 1. Outcome of the 28 patients with thyroid cancer and undetectable pre-ablation thyroglobulin levels and negative TgAb. 
Post-ablation WBS results showed only thyroid bed uptake in the neck in all 28 included subjects, except for one who had mediastinal uptake.

Seventeen patients (61\%) were considered with NED. These patients were followed up for $40 \pm 37$ months after thyroid remnant ablation, and did not show any evidence of recurrent disease. In this group of patients, TNM stages were Stage I: n = $14(82 \%)$; Stage II: $\mathrm{n}=2(12 \%)$ and Stage III: $\mathrm{n}=1(6 \%)$, and risk of recurrence (LATS) was: very low and low for $\mathrm{n}=13(76 \%)$ and high for $\mathrm{n}=4(24 \%)$, whereas ATA recurrence risk was: low $\mathrm{n}=13(76 \%)$ and intermediate $\mathrm{n}=4(24 \%)$.

Four patients (14\%) had persistent/recurrent disease (mediastinum, $\mathrm{n}=1$, lung $\mathrm{n}=2$, unknown $\mathrm{n}=$ 1). The only patient with mediastinal persistence was diagnosed after abnormal uptake in the WBS after the first radioiodine activity of $100 \mathrm{mCi}$ 131-I. Another radioiodine dose of $150 \mathrm{mCi}$ 131-I was administered 12 months later, showing persistent mediastinal uptake, together with abnormal uptake in the same site with the ${ }^{18} \mathrm{FDG}$ in the PET/CT, and stimulated detectable $\mathrm{Tg}$ of $5.4 \mathrm{ng} / \mathrm{mL}$. Mediastinal lymph node dissection was then indicated. One of 7 lymph nodes was positive for metastatic papillary thyroid carcinoma. A new stimulated $\mathrm{Tg}$ level, performed 12 months after surgery, showed persistent detectable $\mathrm{Tg}$ level of $2.4 \mathrm{ng} / \mathrm{mL}$.

Both patients diagnosed with lung metastasis had a post ablation WBS showing only thyroid bed uptake (100 mCi 131-I). The appearance of detectable $\mathrm{Tg}$ level under thyroid hormone suppressive therapy $(2.5$ and $1.9 \mathrm{ng} / \mathrm{mL}, 12$ and 24 months after remnant ablation, respectively) without any other suspicious finding (normal US and chest CT), led us to administrate a second radioiodine dose of $100 \mathrm{mCi}$ 131-I. Post-dose WBS showed diffuse radioiodine uptake in the lungs associated with stimulated Tg level of 69 and $144 \mathrm{ng} /$ $\mathrm{mL}$, respectively. The fourth patient had biochemical persistence with a stimulated Tg level of $2.5 \mathrm{ng} / \mathrm{mL}$ measured 72 hours after two recombinant human TSH injections, without any other sign of disease localization. The TNM stages for three of these patients were IVa (two classic and one tall cell PTC variant), and one patient was staged as IVb with diffuse sclerosing variant of PTC. The risk of recurrence was high for all of them, according to both LATS and ATA classifications.

Seven patients $(25 \%)$ presented $\mathrm{TgAb}$ detection by other IMA methodology in their follow-up (Table 2). All of these patients had diffuse Hashimoto's thyroiditis in the pathological analysis.
Table 2. Laboratory IMA used in the first negative TgAb assessment and in the second detectable TgAb measurement in 7 patients with papillary thyroid cancer

\begin{tabular}{lcc}
\hline Patient & Baseline (undetectable) & Follow-up (detectable) \\
\hline 1 & ChL (Immulite 1000 SM) & EChL (Elecsys 2010 R) \\
2 & ChL (Immulite 2000 SM) & EChL (Elecsys 2010 R) \\
3 & EChL (Elecsys 2010 R) & ChL (Immulite 1000 SM) \\
4 & EChL (Elecsys 2010 R) & ChL (Immulite 2000 SM) \\
5 & ChL (Immulite 1000 SM) & EChL (Elecsys 2010 R) \\
6 & ChL (Immulite 1000 SM) & EChL (Elecsys 2010 R) \\
7 & EChL (Elecsys 2010 R) & ChL (Immulite 2000 SM) \\
\hline
\end{tabular}

ChL: chemiluminescence; EChL: electrochemiluminescence.

Three of these 7 patients were finally considered with NED (undetectable Tg and TgAb in the followup). This situation ocurred $22 \pm 5$ months after remnant ablation. All were TNM stage I, but with high (LATS) or intermediate (ATA) risk of recurrence.

The remaining 4 patients still persisted with detectable $\operatorname{TgAb}$, with no evidence of disease after a mean follow-up of $60 \pm 27$ months.

\section{DISCUSSION}

Thyroglobulin is a specific tumor marker when total thyroidectomy is performed and remnant ablation indicated. Most differentiated thyroid cancer cells synthesize $\mathrm{Tg}$, although there may be differences in the molecular conformation of this tumor-derived $\operatorname{Tg}(13,14)$. The presence of detectable Tg after total thyroidectomy and remnant ablation usually indicates persistence or recurrence of disease (1). Pre-ablation stimulated Tg levels $<10 \mathrm{ng} / \mathrm{mL}$ under hypothyroid conditions has been proven to have a high negative predictive value in the definition of free of disease patients $(15,16)$.

However, serum $\mathrm{Tg}$ measurement remains technically challenging even after 30 years of experience with different assays (17). Despite the introduction of a $\mathrm{Tg}$ reference preparation (CRM 457) more than 10 years ago (18), current methods to measure $\mathrm{Tg}$ still have an unacceptable intermethod variability $(14,19)$, and this issue would need to be addressed before considering $\mathrm{Tg}$ as a marker of the presence of thyroid tissue. On top of that, false negative Tg levels from 4 up to $35 \%$ of DTC patients with evidence of local or metastatic disease have been reported in literature (20-24).

Interference of serum antibodies remain the most serious problem, limiting the clinical utility of Tg testing. $\mathrm{Tg}-\mathrm{Ab}$ is usually detected in around $20 \%$ of patients 
with DTC, compared with the $10 \%$ generally seen in the general population (20). The presence of $\operatorname{TgAb}$ is characterized by discordance in $\mathrm{Tg}$ values between RIA and IMA methodologies (detectable Tg using RIA and low or undetectable Tg using IMA) (14).

When $\mathrm{TgAb}$ are initially detectable, their serum level may decrease over subsequent months and years after adequate therapy, as thyroid tissue mass and $\mathrm{Tg}$ antigen levels decline $(25,26)$. Patients may not achieve negative $\operatorname{TgAb}$ status during the first postoperative year, and may even exhibit a rise (or de novo appearance of $\mathrm{TgAb}$ during the 6 months after a radioiodine treatment, when there is release of $\mathrm{Tg}$ antigen secondary to lytic cell damage of thyroid tissue) $(27,28)$. Clearly, it is the long-term trend in $\mathrm{TgAb}$ concentrations that is more valuable than any single TgAb level per se (29). Kim and cols. found that less than $1 \%$ of patients who became TgAb-negative or displayed more than $50 \%$ decrease in TgAb levels over the 6 to 12 months period after radioiodine treatment had recurrence detected during follow-up. In contrast, 19\% of patients in whom $\mathrm{TgAb}$ decreased less than $50 \%$, as well as the $37 \%$ in whom $\mathrm{TgAb}$ concentrations rose, were diagnosed with recurrence (29).

On the other hand, undetectable Tg levels at the time of ablation may reflect variable situations, according to different publications $(12,16,30,31)$. Almost $30 \%$ of the reported patients in these series have an undetectable $\mathrm{Tg}$ levels after surgery. In our experience, finding undetectable pre-ablation stimulated $\mathrm{Tg}$ levels is not frequent, as it was shown in this study. In a retrospective investigation performed by the Thyroid Department (of the Argentinian Society of Endocrinology and Metabolism), more than $90 \%$ of patients had detectable $\mathrm{Tg}$ levels at the moment of ablation (16). Similarly, we had $9 \%$ of patients of our database with an undetectable pre ablation $\mathrm{Tg}$ level, and only $61 \%$ of them were considered free of disease. Whether this is a condition associated with the surgery technique usually employed in our country or to other circumstances, it remains unclear.

On the other hand, $14 \%$ of these patients with $\mathrm{U}$ Tg had persistent disease. In a study performed by Rosario and cols., the presence of undetectable $\mathrm{Tg}$ at the time of ablation enabled early prediction of long-term outcome of low risk patients (12). On the other hand, $57.7 \%$ of Park and cols. patients with U Tg but positive post-ablation WBS were stage III or IV, and they found regional and distant metastases in $42.3 \%$ of low risk patients (11). In the study of Phan and cols., who specifically analyzed low risk patients with undetectable $\mathrm{Tg}$ at ablation, only $3.4 \%$ of these patients had metastasis on postoperative US or WBS, suggesting that the measurement of a stimulated $\mathrm{Tg}$ at 12-18 months in order to define the disease status was unnecessary (10). We agree that this is true for most patients with $\mathrm{U} \mathrm{Tg}$, but we observed 14\% recurrence (including distant metastatic disease not detected by the measurement of the first stimulated $\mathrm{Tg}$ ). We believe that, in these cases, the method that had been used to measure the first stimulated $\mathrm{Tg}$ level did not detect it accurately, yielding a false negative value. Otherwise, $\mathrm{Tg}$ would not have been detectable on thyroid hormone suppressive therapy 12 and 24 months after thyroid remnant ablation.

Furthermore, $25 \%$ of our patients who had undetectable $\mathrm{TgAb}$ turned out to be positive in successive measurements with other laboratory kits (Table 2). It is probable that if we continued measuring $\mathrm{TgAb}$ with the same IMA methodology, we could have missed these positive $\mathrm{TgAb}$ cases.

Given the high prevalence of $\operatorname{TgAb}$, it is critical to ensure that specimens do not contain TgAb before authenticating a serum $\mathrm{Tg}$ result, because even low levels of $\mathrm{TgAb}$ can interfere with $\mathrm{Tg}$ measurement $(1,2,9,17)$. Interference of serum antibodies remain the most serious problem, limiting the clinical utility of Tg testing. $\mathrm{Tg}-\mathrm{Ab}$ is usually detected in around $20 \%$ of patients with DTC, compared with the $10 \%$ generally seen in the general population (20). The presence of $\mathrm{TgAb}$ is characterized by discordance in Tg values between RIA and IMA methodologies (detectable Tg using RIA and low or undetectable Tg using IMA) $(9,14)$.

Table 2 shows the different kits used for $\mathrm{TgAb}$ measurement in our series. Because of TgAb method variability, the same method needs to be employed for long-term monitoring. This requirement is problematic for laboratories because manufacturers sometimes withdraw or change their methods without any notification. Furthermore, it is not unusual for patients to change physicians and/or insurance plans that offer different laboratories to continue their follow-up.

Although undetectable pre-ablation Tg levels usually indicate complete previous surgery, our data reinforce earlier observations that, in a low percentage of patients, this situation may be related to non-detectable $\mathrm{Tg}$ or to the presence of $\operatorname{TgAb}(12-30,31)$. We believe that, when concurrent chronic thyroiditis is found by the pathologist, or when initial TNM stages are dis- 
cordant with pre-ablation $\mathrm{Tg}$ levels, it is imperative to measure $\mathrm{TgAb}$ with different laboratory kits in order to avoid misdiagnosing a patient with undetectable $\mathrm{Tg}$ level as free of disease.

Disclosure: no potential conflict of interest relevant to this article was reported.

\section{REFERENCES}

1. Cooper DS, Doherty GM, Haugen BR, Kloos RT, Lee SL, Mandel SJ, et al. Revised American Thyroid Association management guidelines for patients with thyroid nodules and differentiated thyroid cancer. Thyroid. 2009;19(11):1167-214.

2. Pitoia F, Ward L, Wohllk N, Friguglietti C, Tomimori E, Gauna A, et al. Recommendations of the Latin American Thyroid Society on diagnosis and management of differentiated thyroid cancer. Arq Bras Endocrinol Metabol. 2009;53(7):884-7.

3. Kumar A, Shah DH, Shrihari U, Dandekar SR, Vijayan U, Sharma SM. Significance of antithyroglobulin autoantibodies in differentiated thyroid carcinoma. Thyroid. 1994;4(2):199-202.

4. Pacini F, Mariotti S, Formica N, Elisei R, Anelli S, Capotorti E, et al. Thyroid autoantibodies in thyroid cancer: incidence and relationship with tumor outcome. Acta Endocrinol. 1988;119(3):37380.

5. Spencer CA, Takeuchi M, Kazarosyan M, Wang CC, Guttler RB, Singer PA, et al. Serum hyroglobulin autoantibodies: prevalence, influence on serum thyroglobulin measurement and prognostic significance in patients with differentiated thyroid carcinoma. J Clin Endocrinol Metab. 1998;83(4):1121-7.

6. Görges R, Maniecki M, Jentzen W, Sheu SN, Mann K, Bockisch A, et al. Development and clinical impact of thyroglobulin antibodies in patients with differentiated thyroid carcinoma during the first 3 years after thyroidectomy. Eur J Endocrinol. 2005;153(1):49-55.

7. Kim WG, Yoon JH, Kim WB, Kim TY, Kim EY, Kim JM, et al. Change of serum antithyroglobulin antibody levels is useful for prediction of clinical recurrence in thyroglobulin-negative patients with differentiated thyroid carcinoma. J Clin Endocrinol Metab. 2008;93(12):4683-9.

8. Seo JH, Lee SW, Ahn BC, Lee J. Recurrence detection in differentiated thyroid cancer patients with elevated serum level of antithyroglobulin antibody: special emphasis on using 18F-FDG PET/ CT. Clin Endocrinol (Oxf). 2010;72(4):558-63.

9. Spencer C, Petrovic I, Fatemi S. Current thyroglobulin autoantibody (TgAb) assays often fail to detect interfering $\operatorname{TgAb}$ that can result in the reporting of falsely low/undetectable serum Tg IMA values for patients with differentiated thyroid cancer. J Clin Endocrinol Metab. 2011;96(5):1283-91.

10. Phan HT, Jager PL, van der Wal JE, Sluiter WJ, Plukker JT, Dierckx RA, et al. The follow-up of patients with differentiated thyroid cancer and undetectable thyroglobulin $(\mathrm{Tg})$ and $\mathrm{Tg}$ antibodies during ablation. Eur J Endocrinol. 2008;158(1):77-83.

11. Park EK, Chung JK, Lim IH, Park do J, Lee DS, Lee MC, et al. Recurrent/metastatic thyroid carcinomas false negative for serum thyroglobulin but positive by posttherapy I-131 whole body scans. Eur J Nucl Med Mol Imaging. 2009;36(2):172-9.

12. Rosario PW, Xavier AC, Calsolari MR. Value of postoperative thyroglobulin and ultrasonography for the indication of ablation and ${ }^{131}$ activity in patients with thyroid cancer and low risk of recurrence. Thyroid. 2011;21:49-53.

13. Schulz R, Bethäuser H, Stempka L, Heilig B, Moll A, Hüfner M. Evidence for immunological differences between circulating and thyroid tissue-derived thyroglobulin in men. Eur J Clin Invest. 1989;19(5):459-63.

14. Spencer CA, Bergoglio LM, Kazarosyan M, Fatemi S, LoPresti JS. Clinical impact of thyroglobulin $(\mathrm{Tg})$ and $\mathrm{Tg}$ autoantibody method differences on the management of patients with differentiated thyroid carcinomas. J Clin Endocrinol Metab. 2005;90(10):556675.

15. Polachek A, Hirsch D, Tzvetov G, Grozinsky-Glasberg S, Slutski I, Singer J, et al. Prognostic value of post-thyroidectomy thyroglobulin levels in patients with differentiated thyroid cancer. J Endocrinol Invest. 2011;34(11):855-60.

16. Cabezón C, Löwenstein A, Orlandi A, Sartorio G, Sobrado P y Miembros del Departamento de Tiroides de la Sociedad Argentina de Endocrinología y Metabolismo (SAEM). Usefulness of preablation serum thyroglobulin as a predictor of the evolution of patients with differentiated thyroid carcinoma. Rev Arg Endocrinol Metab. 2011;48(4):25-33.

17. Spencer CA, Lopresti JS. Measuring thyroglobulin and thyroglobulin autoantibody in patients with differentiated thyroid cancer. Nat Clin Pract Endocrinol Metab. 2008;4(4):223-33.

18. Feldt-Rasmussen $U$, Profilis $C$, Colinet $E$, Black $E$, Bornet $H$, Bourdoux $P$, et al. Human thyroglobulin reference material (CRM 457). 2nd Part: Physicochemical characterization and certification. Ann Biol Clin (Paris). 1996;54(10-11):343-8.

19. Spencer CA, Takeuchi M, Kazarosyan M. Current status and performance goals for serum thyroglobulin assays. Clin Chem. 1996;42(1):164-73.

20. Spencer CA, Takeuchi M, Kazarosyan M, Wang CC, Guttler RB, Singer PA, et al. Serum thyroglobulin autoantibodies: prevalence, influence on serum thyroglobulin measurement, and prognostic significance in patients with differentiated thyroid carcinoma. J Clin Endocrinol Metab. 1998;83(4):1121-7.

21. Grant S, Luttrell B, Reeve T, Wiseman J, Wilmshurst E, Stiel J, et al. Thyroglobulin may be undetectable in the serum of patients with metastatic disease secondary to differentiated thyroid carcinoma. Follow-up of differentiated thyroid carcinoma. Cancer. 1984;54(8):1625-8.

22. Westbury C, Vini L, Fischer C, Harmer C. Recurrent differentiated thyroid cancer without elevation of serum thyroglobulin. Thyroid. 2000;10(2):171-5.

23. Mertens IJ, De Klerk JM, Zelissen PM, Thijssen JH, Sie-Go DM, Han $\mathrm{SH}$, et al. Undetectable serum thyroglobulin in a patient with metastatic follicular thyroid cancer. Clin Nucl Med 1999;24(5):346-9.

24. Brendel AJ, Lambert B, Guyot M, Jeandot R, Dubourg H, Roger $P$, et al. Low levels of serum thyroglobulin after withdrawal of thyroid suppression therapy in the follow-up of differentiated thyroid carcinoma. Eur J Nucl Med. 1990;16(1):35-8.

25. Görges R, Maniecki M, Jentzen W, Sheu SN, Mann K, Bockisch A, et al. Development and clinical impact of thyroglobulin antibodies in patients with differentiated thyroid carcinoma during the first 3 years after thyroidectomy. Eur J Endocrinol. 2005;153(1):4955.

26. Chiovato L, Latrofa F, Braverman LE, Pacini F, Capezzone M, Masserini $L$, et al. Disappearance of humoral thyroid autoimmunity after complete removal of thyroid antigens. Ann Intern Med. 2003;139(5):346-51.

27. Rubio IG, Silva MN, Knobel M, Romao R, Possato R, Gebrin EM, et al. Peripheral blood levels of thyroglobulin mRNA and serum thyroglobulin concentrations after radioiodine ablation of multinodular goiter with or without pre-treatment with recombinant human thyrotropin. J Endocrinol Invest. 2007;30(7):535-40.

28. Benvenga S, Bartolone L, Squadrito S, Trimarchi F. Thyroid hormone autoantibodies elicited by diagnostic fine needle biopsy. $J$ Clin Endocrinol Metab. 1997;82(12):4217-23. 
29. Kim WG, Yoon JH, Kim WB, Kim TY, Kim EY, Kim JM, et al. Change of serum antithyroglobulin antibody levels is useful for prediction of clinical recurrence in thyroglobulin-negative patients with differentiated thyroid carcinoma. J Clin Endocrinol Metab. 2008;93(12):4683-9.

30. Tuttle RM, Tala H, Shah J, Leboeuf R, Ghossein R, Gonen M, et al. Estimating risk of recurrence in differentiated thyroid cancer after total thyroidectomy and radioactive iodine remnant ablation: using response to therapy variables to modify the initial risk estimates predicted by the new American Thyroid Association staging system. Thyroid. 2010;20(12):1341-9.

31. Vaisman F, Shaha A, Fish S, Tuttle R. Initial therapy with either thyroid lobectomy or total thyroidectomy without radioactive iodine remnant ablation is associated with very low rates of structural disease recurrence in properly selected patients with differentiated thyroid cancer. Clin Endocrinol (Oxf). 2011; Feb 8. doi: 10.1111/j.1365-2265.2011.04002.x. [Epub ahead of print] 